\title{
DINASTI POLITIK PEMERINTAH DESA DI KABUPATEN POLEWALI MANDAR
}

\author{
Pahruddin \\ Fakultas Ilmu Sosial dan Ilmu Politik, Universitas Sulawesi Barat \\ Email: pahruddinsamsia@yahoo.com
}

\begin{abstract}
Patjiddai family has maintain its succes in the village administration of Katumbangan.The study aims to investigate the causes enabling the village leader dynasty to survive in one family of the community of Katumbangan Village, of Campalagian Districk even though the election was conducted directly and open to the members of the community. The study was located in Katumbangan Village of Campalagian District of Polewali Mandar Regency, West Sulawesi. The Study was a qualitative research with a case study. The informant were selected based on the purpose of the study: the head of the village, public figures, the village election committee, the chairperson of Regional Development Board (BPD), the village government officials. The data were collected by means of in-depth interview, observation, and documentary study. Qualitative analysis was applied to the study.The study indicates that the survival of Patjiddai Dynasty in holding the post as the village head are due to several strong and solid supporting factors which depend this dynasty in the village leader election process. This dynasty makes use of the resources of its loyal supporters or patron clans and economic factors of natural resources controlled by this dynasty. The success is also supported by the elite members of the Katumbangan comminity successfully mobilised to support any candidate from the Patjiddai family.
\end{abstract}

Keywords: political dynasty, patron clans, village head election.

\begin{abstract}
ABSTRAK
Keluarga Patjiddai dalam Pilkades berhasil tetap bertahan dalam Pemerintahan Desa Katumbangan .Penelitian ini bertujuan menganalisis pola dan penyebab sehingga Dinasti kepala desa bertahan pada satu keluarga meskipun pemilihan telah diadakan secara langsung dan terbuka bagi. Lokasi penelitian ini lokasi penelitian ini didesa Katumbangan Kecamatan Campalagian Kabupaten Polewali Mandar Propinsi Sulawesi Barat. Penelitian kualitatif mengunakan studi kasus. Penentuan informan dilakukan dengan teknik purposive. Informan penelitian ini yakni kepala desa, tokoh masyarakat, Panitia Pilkades, ketua BPD dan penjabat desa. Teknik pengumpulan data melalui wawancara mendalam, observasi, dan studi pustaka.Hasil penelitian ini menunjukkan bahwa bertahanya dinasti Patjiddai dalam jabatan kepala desa pada pemerintah Desa Katumbangan karena adanya beberapa faktor pendukung yang sangat kuat dan solid dalam mempertahankan dinasti tersebut, untuk mempertahankan jabatan sebagai kepala desa, dinasti patjiddai pada proses Pilkades mengerakkan sumber daya yang benar-benar mendukung dengan sepenuh hati dan faktor ekonomi, serta sumber alam yang dikuasai oleh dinasti patjiddai. Keberhasilan dalam mempertahankan dinasti juga ditunjang oleh elit masyarakat desa katumbangan yang berhasil digerakkan untuk tetap mendukung calon dari keluarga patjiddai.
\end{abstract}

Kata kunci : Dinasti politik, patron klein, pemilihan kepala desa. 


\section{Pendahuluan}

Pemilihan Kepala Desa, seperti hajatan demokrasi yang lain sebenarnya juga membuka jalan bagi pembaharuan desa. Hasil Pemilihan Kepala Desa, sesungguhnya jabatan politis yang kuat legitimasinya dan berdaulat. Dengan kekuasaannya Kepala Desa mempunyai kewenangan untuk mengeluarkan peraturan (Perdes) dengan persetujuan Badan Permusyawaratan Desa. Semacam kontrak politik, masyarakat pedesaan juga bisa memanfaatkan momentum Pemilihan Kepala Desa untuk mencari sosok Kepala Desa yang penuh komitmen untuk pembaharuan desa, daripada terus menerus dibohongi janji-janji semu politik uang (Dhuroruddin dkk., 2005).

Sebagai proses politik dalam demokrasi langsung yang paling mendasar, pilkades bisa dijadikan pembelajaran berpolitik dan berdemokrasi yang baik yang dapat menghasilkan pilihan yang benar dan tepat, baik secara kapabilitas maupun kapasitas. Hasil akhir dari pilihan rakyat, dalam berdemokrasi apapun hasilnya, jika sudah menjadi keputusan bersama harus bersama-sama diterima dan dikawal dalam pelaksanaan pemanfaatan jabatan. Diperlukan pikiran yang obyektif, lepas dari dendam dan pengaruh subyektif lain dalam menentukan pilihan bagi semua rakyat yang punya hak suara (Wahyuni, 2004).

Dalam pelaksanaan pemilihan Kepala desa pada zaman orde baru sampai orde reformasi menpunyai karakter yang berbeda dimana pada zaman orde baru jabatan kepala desa sering berorientasi tertutup sehingga jabatan ini hanya pada elite lit tertentu saja sedangkan pada zaman reformasi lebih terbuka dimana dalam proses pemilihan langsung.

Sebagai sebuah proses politik tingkat paling bawah, pilkades sering menjadi sebuah pergelaran demokrasi untuk memilih calon pemimpin disebuah desa. Namun terkadang pemilihan kepala desa kurang memperhatikan kapabilitas si calon. Unsur kekerabatan menjadi bagian penting bagi bagi si calon apakah ia menang atau tidak . unsur kekerabatan dalam suatu wadah keluarga besar akan menjadi sangat berpengaruh di desa- desa yang penduduknya masih dominan penduduk asli, dan akan berbeda diperkotaan. Rasa persaudaraan menjadi pertimbangan tertinggi dalam memilih, motivasi - motivasi lain yang sifa tnya subyektif juga berpengaruh seperti, faktor keturunan atau sratifikasi sosial

Rekruitmen politik yang terbuka pada masa reformasi ditandai dengan semakin beragamnya kontestan yang mengikuti pemilihan Kepala Desa. Mereka berasal dari berbagai latar belakang dan ideologi politik yang berbeda. Dalam masyarakat terdapat sratifikasi kekuasaan yang dimiliki yaitu yang memiliki kekuasaan disebut elit (pemimpin). Dan yang tidak memiliki kekuasaan disebu elit massa rakyat (Surbakti, 1999). 
Melihat dari kondisi pemilihan kepala desa yang betul-betul terbuka ini persaingan antar elit desa dalam pemilihan kepala desa benar-benar mengandalkan kekuatan politik mereka sendiri untuk meraih dukungan masyarakat (pemilih). Elit yang menjadi calon kepala desa harus memiliki berbagai keunggulan sumber daya agar para pemilih yakin bahwa mereka layak menjadi pemimpin tertinggi didesanya (Orbawati, 2005). Menurut Vilfredo Pareto percaya bahwa dalam setiap kelompok terdapat orang-orang yang terbaik yang diperlukan kehadiranya pada kekuasaan yang penuh dan merupakan elit itu berada dari latar belakang yang sama, yang memilki kelebihan dalam kekayaan dan kecerdasan (Gatara, 2009).

Dalam persaingan dalam mencari peminpin pada pemilihan kepala desa ini incumbent atau kepala desa sebelumnya akan berusaha keras agar estafet kepemimpinan didesa tersebut tetap didalam trah keluarganya, menjadi kepala desa adalah sebuah hal kebanggaan tersendiri dalam masyarakat. Dengan sistem kepemimpinan desa yang hanya bisa berlangsung selama 2 periode masa jabatan kepala desa, sehingga persaingan elit dalam proses pemilihan kepala desa ini terbuka peluang yang sama untuk berkopetensi dalam pemilihan kepala desa, kepala desa sebelumnya atau elit keluarga tidak akan melepas jabatan tersebut diluar trah keluarganya sehingga harus didistribusikan atau melingkar hanya kepada yang memiliki hubungan keluarga (Komar, 2013).

Dalam pemilihan kepala desa ini yang penulis coba ungkapkan ini terjadi Connection Fower yaitu kekuasaan karena seseorang memiliki hubungan kekerabatan dengan seseorang yang berkuasa sebelumnya (Syafi'ie, 2009). Dengan model Connection Fower ini terjadi pelimpahan kekuasaan dalam masyarakat dengan praktek penerusan kekuasaan pemerintahan desa kepada orang-orang terdekatnya sehingga fenomena ini dapat diartikan sebagai pola penerusan kekuasaan kepada keturunanya dan secara turun temurun.

Politik dinasti secara sederhana dapat diartikan sebagai praktik kekuasaan dimana anggota keluarga (sanak famili) diberi atau tetap didalam sruktur kekuasaan pemerintahan sehingga kekuasaan itu hanya terdistribusi dikalangan kerabat, keluarga sedarah. Secara umun politik dinasti adalah proses mengarahkan regenerasi kekuasaan bagi kepentingan golongan tertentu untuk bertujuan mendapatkan atau mempertahankan kekuasaan disuatu pemerintahan. Dinasti politik yang dalam bahasa sederhana dapat diartikan sebagai sebuah rezim kekuasaan politik atau aktor politik yang dijalangkan secara turun temurun atau dila kukan salah satu keluarga atau kerabat dekat (Komar, 2013).

Dinasti politik ini juga mempunyai aspek positif karna figur yang tampil sebagai calon Kepala Desa sudah lebih dikenal masyarakat dan sudah menjalai pendidikan politik di dalam keluarganya, sehingga memiliki modal politik. Figur ini sudah memiliki rekam jejak politik yang panjang sesuai dengan perjalanan keluarganya.

Tujuan pokok dari penelitian ini adalah menganalisis pola dan penyebab dinasti politik dalam pemerintahan desa dengan adanya persaingan yang sangat ketat dalam pemilihan 
langsung kepala desa yang dipenuhi persaingan politik elit tertentu, dimana sebuah 3Reluarga dalam mempertahankan trah atau dinasti politiknya dalam sebuat tata pemerintahan desa adalah pencapaian atau kekuatan politik yang sangat tersruktur sehingga keluarga ini tetap memegang jabatan Kepala Desa dalam pemerintahan di Desa katumbangan.

\section{Bahan dan Metode Penelitian}

\section{Lokasi Penelitian.}

Berdasarkan pokok masalah yang penulis utarakan diatas, maka penulis menentukkan penelitian ini pada satu desa yaitu Desa Katumbangan Kecamatan Campalagian Kabupaten Polewali Mandar Propinsi Sulawesi Barat denga alasan desa ini adalah salah satu desa yang Jabatan Kepala Desa adalah dijabat oleh satu trah keluarga saja, dengan melihat kondisi integral penelitian ini juga didasari : lingkungan umun sudah dikenal, subjek penelitian sudah dikenal, baik nama maupun karakternya, denah lokasi sudah difahami, iklmi yang ada sudah makin sesuai, kebiasaan-kebiasaan lokal sudah mulai dikenal; dan lain-lain (Danim, 2002).

\section{Penentuan informan penelitian.}

Dalam menentukkan informan penelitian ini pada penelitian ini adalah memakai metode teknik purposive. Dalam metode purposive ini penentuan informan dilakukan secara sengaja atau dipilih dengan melihat situasi sosial tertentu yang saraf informasi sesuai dengan fokus penelitian (Bungin, 2002). Dengan memakai teknik ini, penulis melihat akan situasi sosial masyarakat desa yang sangat sulit memberi informasi tentang perseoalan politik ditingkat desa. Sehingga dengan memakai metode ini penulis menentukkan informan berdasarkan analisa bahwa informan ini adalah sunyek utama penulis, adapun informan yang penulis wawancarai adalah Kepala Desa yang sementara menjabat sebagai Kepala Desa. Perangkat desa, Tokoh Masyarakat/ Tokoh Agama yang banyak terlibat dalam kegiatan Pemerintah Desa, Ketua dan Anggota Badan Permusyawaratan Desa, dan Panitian Pemilihan Kepala Desa yang mana informan ini adalah semuanya penduduk asli dan sejak kecil hidup di Desa Katumbangan sehingga informan ini betul-betul mengetahui keadaan politik yang terjadi dalam Pemilihan Kepala Desa.

\section{Metode Pengumpulan Data.}

Kegiatan pengumpulan data merupakan langkah yang sangat penting dalam suatu kegiatan penelitian, sebab data tersebut akan diolah sedemikian rupa untuk memperoleh suatu kesimpulan yang sesungguhnya. Metode yang diterapkan dalam pengumpulan data ini adalah: Wanwancara Mendalam, wawancawa dilakukan dengan pertemuan dua orang atau lebih dengan penulis dan masyarakat (Bungin, 2002). serta wawancara elit dimana kalau ingin mengetahui institusi politik beroperasi, bagaimana keputusan penting dibuat, bagaimana kekuasaan politik diraih, kita tidak akan bertanya kepada publik umun tetapi pada akses level informasi yang biasa disebut elit politik (Harrison, 2009) Dokumentasi, dengan mencari datadata penunjang seputar Sejarah Pemerintahan Desa Katumbangan dan proses Pemilihan 
Kepala Desa Katumbangan Kecamatan Campalagian. Observasi, dengan melihat langsung proses pemilihan Kepala Desa yang terjadi dan mencocokkan dengan data wawancara penulis dengan Panitia Pemilihan Kepala Desa

\section{Teknik Analisa Data.}

Teknik analisa data yang dipakai dalam penulisan ini adalah Teknik Analisis Kompenesional dengan melihat gejala-gejala sosial yang memiliki persamaan unsur, dipisahkan atau tidak tetap akan mengelompokan secara ilmiah ( Bungin, 2002).

\section{Hasil Penelitian}

Domininasi politik dinasti patjiddai di desa katumbangan telah dirintis sejak lama bahkan sebelum kemerdekaan dimana masih dinamakan kampung atau masih dalam masa kerajaan Balanifa, kampung Katumbangan sudah berdiri dan kampung ini dijabat memang dari keluarga Patjiddai sampai sekarang. Walaupun sruktur politik nasional maupun lokal mengalamai perubahan yang fudamental, dari rezim yang sentralistik dan otoriter ke rezim yang demokratis, namun perubahan sruktur politik tersebut tidak mampu meruntuhkan dominasi sebuah dinasti politik yang berlangsung di tingkat desa. Eksistensi Dinasti Patjiddai pada puncak kekuasaan di Katumbangan karena kemanpuannya mempergunakan jaringan patronase yang terkonversikan melalui jaringan kleintelistik sebagai dukungan politik yang terus berkembang dan tak berubah sepanjang zaman serta berkelanjutan dan kepemimpinan yang diterapkan, dalam menerapkan metode kepemimpinan yang diterapkan melalui pendekatan perilaku pribadi denga metode non formal yang tidak resmi dengan memakai kebijaksanan secara pribadi tanpa melihat latar belakang masyarakat. Dari cara memimpin masyarakat selalu merasa hanya kepemimpinan dari keluarga patjiddai yang dianggap bisa memimpin merekan di Desa Katumbangan. Legitimasi kekuasaannya diperoleh karena kemanpuan menjaga soliditas keluarga inti (elit dinasti) dan sumberdaya ditingkat patronnnya pada bidan ekonomi sangatlah kuat dan berhasil dalam membangun jaringan klein yang tetap tergantung dan tak lepas akan pengaruhnnya sebagai jaringan yang kuat. Hal itu juga dibarengi juga tetap kemanpuan memelihara soliditas diluar keluarga Dinasti Patjiddai sehingga jaringan klein juga bisa terbangun dan tetap dalam stabil dalam mencari dukungan politik.

Dalam setiap pemilihan Kepala Desa tidak pernah ada persaingan diantara keluarga dari Dinasti Patjiddai untuk menjadi Calon Kepala Desa lebih dari dua orang sehingga dukungan dan soliditas trah keluarga Patjidda tetap solid. Kemanpuan menjaga soliditas juga diterapkan dalam jaringan yang sudah terbangun pada orang tua dari masyarakat 
Katumbangan, bahwa tanpa keluarga patjiddai yang menolong kita pada masa sulit mungkin kita sudaH meninggal dalam kelaparan. Hal ini tersimpan dan dijadikan cerita sejarah penyemangat dalam kepeminpinan pemerintahan desa di Katumbangan.

Argumen ini menegaskan bahwa dalam membangun dan memperkuat Kepemimpinan dalam Trah Dinasti politik Desa sangat tergantung pada kemanpuan mengelola beberapa hal sehingga dinasti ini ada dalam pemerintahan desa, Pengikut ini jaringan klien yang terdiri dari ikatan kekerabatan dan orang orang dekat dalam sriktur pemerintahan desa dan organisasi desa, Penguasaan terhadap sumber-sumber ekonomo dan akumulasi kekayaan yang dimiliki, Kemanpuan memelihar soliditas jaringan klien dan kekerebata keluarga dan kekuata-kekuatan di luar sruktur pemerintahan desa dan organisasi desa yang difungsikan sebagai mesin mobilisasi massa untuk meraih kekuasaan dan tetap melindunggi kekuasaan itu dalam jaringan keluaga Patjiddai.

Sebagai keluarga yang kaya dan dermawan, Dinasti Patjiddai melihat disribusi sumber daya patron sebagai sebuah kewajiban untuk berbagi dengan warga desa lainnya melalui ruang-ruang yag disediakan oleh sruktur sosial dan ekonomi setempat. Artinya distribusi sumber daya patron tersbut merupakan bentuk kepekaan sosial sebuah dinasti politik terhadap lingkungannya tanpa disertai dengan motif politik. Sebagaimana orang yang pernah menerima jasa-jasa baik, bantuan dan pekerjaan atau jabatan, maka para klein berusaha membalas kebaikan-kebaikan tersebut dengan tetap setia berada dalam jaringan klein. Mereka berusahan mengidetifikasikan diri sebagai klien yang setia kepada patron dengan memberikan dukungan dan mobilisasi suara pada pemilihan Kepala Desa atau pemilihan daerah lainnya.

\section{Pembahasan}

Dalam pembahasan tentang Dinasti Politik pemerintahan Desa yang penulis kaji, menemukan bahwa yang membuat Dinasti Patjiddai tetap bertahan juga adalah jaringan patron-klein yang sangatlah kuat dan susah dilepas dalam masyarakat Katumbangan adalah banyaknya masyarakat yang menempati lahan atau tanah yang dimiliki oleh keluarga patjiddai, masyarakat Katumbangan bisa membangun rumah diatas tanah milik keluarga Patjiddai ini dengan status pinjaman dan masyarakat juga ada yang bekerja dilahan pertanian yang dimiliki oleh keluarga patjiddai ini, sehingga hubungan antara patron keluarga patjiddai ini sangatlah erat dengan klein dari masyarakat katumbangan. Masyarakat dalam hubungan patron-klein ini juga sangatlah erat karna keluarga patjiddai sangatla memperhatikan akan masyarakat yang jadi kleinnya ini, sehingga yang namanya hutang budi sangatlah diinggat dan dipegang erat dalam masyarakat Katumbangan. 
Dalam Pemilihan Kepala Desa yang dilakukan di Desa Katumbangan ini, Dinasti Keluarga Patjiddai ini memakai srategi dengan pembauran pada trah kekeluargaan dan jaringan elit klein yang telah terbangun dari awal sehingga dalam masa kampanye dan keluarga dari Dinasti Patjiddai yang mencalonkan diri tidak terlalu memikirkan metode kampanye atau kegiatan politik dalam meraih suara pada pemilihan Kepala Desa, karna sudah ada suara yang signifikan dari kleinnya, apalagi kalau klien ini diberi wewenang juga untuk mencari atau mempengaruhi masyarakat agar memilih calon Kepala Desa dari keluarga dinasti Patjiddai ini.

Menurut sejarahnya bahwa pernah masyarakat Katumbangan dilanda paceklik atau kelaparan dengan dasar kepemimpinan dari keluarga patjiddai ini merasa harus membantu dengan ikhlas dan betul-betul supaya masyarakat yang dipimpinanya ini tidak kelaparan, dengan kejadian ini, keluarga patjiddai ini turun langsung memberikan bantun materi berupa makanan dan air pada keluarga yang kelaparan dan bantuan ini dibawakan langsung kepada masyarakatnya, metode yang dipakai dalam kepemimpinanya ini adalah turun langsung kepada masyarakat dan apabila ada masyarakatnya dilihat kesulitan tanpa memerintah langsung, keluarga patjiddai langsung itu hari memberikan bantuan apa yang diperlukan oleh masyarakatnya.

Sejarah Awal Pemerintahan yang dibangun oleh Dinasti Patjiddai dalam menjalankan kepemimpinan Pemerintahan Desa sangatlah merakyat dan berbaur dengan masyarakatnya, dimana dari sumber yang penulis wawancarai bahwa dalam pembauran dengan masyarakatnya dulu, Keluarga Patjiddai sangatlah merakyat dengan selalu melihat apa kesulitan dan apa maunya masyarakatnya, pernah dalam masa kepemimpinan keluarga Patjidai ini terjadi namanya kekeringan yang melanda masyarakat katumbangan, dalam masa ini masyarakat betul betul kekurangan makanan dan air, kepala desa yang menjabat pada masa itu yakni dari keluarga Patjiddai turun langsung melihat masyarakatnya apakah ada yang kekurangan makanan, dan kalau didapat ada masyarakatnya yang kekurangan makanan, kepala desa langsung turun tangan sendiri membawakan bahan- bahan pokok makanan kepada masyarakat tersebut, dan apabila kekurangan air, maka akan dibawakan ember berisi air sehingga masyarakatnya tidak ada yang mengeluh bahwa terjadi kekeringan pada mas itu, kepemimpinan ini diterapkan dengan terus menerus selama beberapa periode sehingga masyarakat golongan tua selalu meneruskan cerita tersebut kepada keturunanya, dengan cerita, bahwa dengan pertolongan dari Keluarga Patjiddai ini kita tetap bisa hidup sampai 
Kekuasaan dari segi kekayaan ini juga sangat mempengaruhi akan langgengnya hubungan patron Klein dalam masyarakat Katumbangan, dinasti Patdjiddai yang berkedudukan sebagai bangsawan yang berkedudukan di Katumbangan mempunyai kekayaan beberapa lahan tanah, memperkuat akan kekuasaan Patron Klein pada masyarakat dengan adanya kekuasaan akan lahan tanah garapan yang luas ini, Dinasti Patjiddai ini berhasil merekrut beberapa tenaga dari masyarakat Katumbangan sebagai pekerja dilahan pertanian yang dimilikinya sehingga pekerja ini akan selalu merasa sebagai Klein dari keluarga Patjiddai sebagai patronnya.

Hal lain yang dilakukan Keluarga Patjiddai untuk memperkuat patronnya adalah mengizinkan masyarakat katumbangan menempati lahan yang dimiliki keluarga Patjiddai untuk membangun rumah diatas lahan tersebut. Keluarga yang membangun diatas lahan keluarga Patjiddai ini hanya membangun rumah tanpa menpunyai dasar sebagai pemilik tanah tersebut.

Kewibawaan patronase dalam membangun hubungan yang semakin erat ini dimulai dengan kesamaan-kesamaan, kedua jenis hubungan ini merupakan hubungan vertical, dwitunggal dan asimetris. Patron dan klein adalah seseorang yang memantapkan dirinya sebagai perantara yang mutlak diperlukan antara sekelompok yang memiliki beraneka ragam ketrampilan yang saling melengkapi. Baik para patron maupun klein tertekan secara hubungan timbal balik dengan adanya Klein yang memberikan imbalan secara sukarela akan tenaganya, hak suaranya dan dalam beberapa kasus bahkan nyawanya sekalipun.

Dalam mengkaji tentang elit politik dalam masyarakat desa biasa dibedakan dalam pola kalangan kelas atas dan kalangan kelas bawah masyarakat. Dalam pembangian ini kalangan kelas atas atau yang lebih dikenal dengan sebutan elit adalah orang-orang yang memiliki jabatan formal dalam pemerintahan dan kelembagaan ataupun memiliki kekuasaan dari segi materi. Sedangkan kalangan kelas bawah atau yang disebut massa adalah kelompok mayoritas masyarakat yang dikuasai elit serta kurang diperhitungkan dalam pengambilan keputusan.

\section{Kesimpulan}

Adanya jaringan kekuasaan yang dibangun oleh Dinasti Patjiddai dari awal sampai sekarang dan rasa kekeluargaan serta kebersamaan diantara keluarga besar Patjiddai dalam membangun eksistensi di desa Katumbangan agar lebih maju, menimbulkan rasa kebersamaan diantara masyarakat katumbangan untuk tetap memilih Kepemimpinan dalam Pemerintahan Desa Katumbangan secara turun temurun dan diwariskan kepada Keluarga Patjiddai meskipun Pemilihan Kepala Desa secara langsung,umun bebas dan jurdil serta dilakukan 
secara demokratis. Dalam negara yang menganut sistem demokrasi. Dengan bentuk sistem pemilu yang mewakili rakyat dalam menjalankan pemerintahan dengan memilih wakil atau pemimpin pemerintah. Pemilihan yang dilakukan pada pemilihan desa yang perlu dijadikan contoh sebagai sebuah demokrasi yang penuh kekeluargaan dan keakraban diantara konstentan calon Kepala Desa dalam Pilkades. Dalam pemilihan kepala desa, komitmen diantara calon sangatlah besar dalam menegakkan siap menang atau kalah dalam pemilihan Kepala desa sehingga budaya kekeluargaan dan gotong royong setelah Pilkades tetap berjalan dan diantara elit politik yang terlibat dalam Pilkades tidak ada yang saling dendam.

\section{Daftar Pustaka}

[1] Bungin Burhan. (2012). Analisis Data Penelitian Kualitatif. Jakarta. PT Raja Grafindo Persada.

[2] Danim Sudarwan. (2002). Menjadi Peneliti Kualitatif. Bandung. Pustaka Setia.

[3] Dhurorudin Mashad, dkk. ( 2005). Konflik Elit Politik Pedesaan. Yogyakarta: Pustaka Pelajar.

[4] Harrison Lisa. (2009). Metodologi Penelitian Politik. Jakarta. Kencana

[5] Komar Samsul. (2013). Dinasti Kepala Desa (tesis). Yogyakarta: Universitas Gajah Mada.

[6] Orbawati Eny Boedi. (2005). Demokrasi Desa Dalam Kajian Otonomi Daerah. Magelang: FISIP Universitas Magelang.

[7] Gatara Sahid. (2009). Ilmu Politik (Memahami dan Menerapkan). Bandung. Pustaka Setia. Surbakti Ramlan. (1999). Memahami Ilmu Politik. Jakarta. Grasindo.

[8] Syafi'ie inu kencana. (2009). Kepemimpinan Pemerintahan Indonesia. Bandung. Refika Aditama

[9] Wahyuni Sri. (2004). Demokratisasi Pemerintahan Desa (Tesis) . Semarang: Universitas Diponegoro. 